\title{
An Analytical Model of the Institutional Design of Specialized Anti-corruption Courts in the Global South: Brazil and Indonesia in Comparative Perspective
}

\author{
Lígia Mori Madeira ${ }^{1}$ \\ Leonardo Geliski ${ }^{\circledR}$ \\ 1Professor in the Department of Political Science of the Federal University of Rio Grande do Sul (UFRGS). \\ Porto Alegre, RS. Brazil. \\ E-mail: ligiamorimadeira@gmail.com \\ ${ }^{2} \mathrm{PhD}$ candidate in Public Policy from the Federal University of Rio Grande do Sul (UFRGS). Porto Alegre, \\ RS. Brazil. \\ E-mail: leonardo.geliski@ufrgs.br
}

\section{INTRODUCTION}

$\mathrm{T}$

This article introduces the Brazilian experience of fighting corruption through specialized courts as one of the cases in the Global South. It presents the creation of Brazil's specialized courts, their characteristics, and convergences and divergences in comparison with the well-known case of the specialized court of Indonesia. The study helps fill a gap in the literature on the subject by describing the process of these courts' creation from the perspective of judges and policymakers and proposing an analytical model of the institutional design of the specialized anti-corruption courts. It also contextualizes the national experience in Brazil within the panorama of the developing countries of the Global South, focusing on the role of anti-corruption agendas promoted by international organizations and multilateral agencies.

\footnotetext{
"We thank the School of Justice of the Queensland University of Technology (Brisbane), in the person of Profa. Kerry Carrington, who received us during our research, allowing the development of a significant part of this study. We are also grateful to Prof. Simon Butt (Centre for Asian and Pacific Law at the University of Sydney), discussions with whom resulted in the idea to compare Brazil and Indonesia. We also thank Prof. Rogério Arantes for his comments on the preliminary version of the article presented at the Anpocs Annual Meeting. We appreciate the comments of the anonymous referees of DADOS. This work integrates the research project Federal Justice in the formulation and implementation of a national anti-corruption policy, awarded with a PQ2 CNPq (Conselho Nacional de Desenvolvimento Científico e Tecnológico) grant.
}

DADOS, Rio de Janeiro, vol.64 (3): e20190191, 2021

https://doi.org/10.1590/dados.2021.64.3.240 
The analytical model proposed seeks to understand the establishment of specialized courts as a public policy for fighting corruption. The adoption of parameters related to policy-making processes such as agenda-setting, policy formulation, institutional design, and the bureaucracy involved in such courts is understood to be of crucial importance in this model. Other elements associated with public policies and observed in the model are the courts' performances, and internal support for the specialized courts (from the judicial branch) and external (from other government branches and higher courts), as well as the durability of the specialized anti-corruption courts compared to specialized anticorruption agencies operating in other government branches.

The study explores the literature on the issue, adopting a qualitative approach, and analyzing reports of multilateral agencies, legislative and judicial documents. Interviews were conducted with experts and professionals working in the judicial system and involved in the formulation and implementation of the specialized courts in Brazil ${ }^{1}$.

The article is organized into seven sections, including this introduction. The next section contextualizes the anti-corruption agenda, the main international recommendations regarding practices and legislation, and the measures adopted to institutionalize anti-corruption practices and legislation in other countries. The third section presents the concept of specialized courts and their operation regarding the issue of corruption. The fourth section presents the history, operation, and crisis of the Indonesian anti-corruption court. The fifth section focuses on Brazil's specialized federal anti-corruption courts. It presents the main political events and institutional changes in recent decades related to the role of the federal justice system and specialized courts in national anti-corruption policy. Finally, the article presents the proposed analytical model for the institutional design of the specialized anti-corruption courts and reflections on the consolidation of the specialized courts.

\section{ANTI-CORRUPTION AS AN INTERNATIONAL AGENDA}

Corruption has deleterious effects on the economies and development of countries since it discourages foreign investment, reduces tax collection, jeopardizes public services, and aggravates socio-economic 
inequalities and poverty. Therefore, in recent decades, corruption has become a concern for international organizations and multilateral agencies operating in developing countries (De Sousa, 2010).

In the 1990s, anti-corruption activity was characterized by the emergence of new actors such as independent specialized anti-corruption agencies (ACAs), and public agencies designed to fight, prevent, and suppress corruption (De Sousa, 2010:5).

Building on the model of the first anti-corruption agencies established in Asia (in Singapore and Hong Kong) after the decline of the colonial period, independent agencies expanded their operations from developing to developed countries, from societies in transition to consolidated democracies (usually after specific scandals), making the fight against corruption a global effort:

ACAs are often born from a broad political consensus in a context of scandal and crisis, which helps to explain the short existence of some of these bodies or their limited capacity to deliver results. Following the perceived failure of conventional law enforcement bodies (police, courts, attorney-general offices, etc.), ACAs are often regarded by governments, donors, and international governmental organizations (IGOs) as the ultimate institutional response to corruption (De Sousa, 2010:6).

The domestic context of the creation of the agencies is linked to the international environment, with global institutions recommending the creation of ACAs and the adoption of institutional anti-corruption structures and strategies. However, the structures and their effectiveness vary significantly from country to country. While there is a tendency for one country or agency to copy the actions of another, ACAs are the product of specific patterns of legal and institutional development and each experience is unique due to the specific powers they are granted, their scope of action, the resources available, and the requirements regarding accountability (De Sousa, 2010:7).

During the 1990s, multilateral agencies and regional and international organizations (including the Organization of American States, United Nations, European Union, African Union, Council of Europe, the Organization for Economic Co-operation and Development, International Monetary Fund, and World Bank) recommended the adoption of 
international principles and conventions that criminalize bribery by public servants, encourage harmonization of criminal laws and procedures, and facilitate international cooperation in criminal matters. Anti-corruption networks were created to increase the ability of state institutions to fight corruption. The public policies initially designed to address government corruption were adopted by companies, increasing the role of civil society in controlling corruption (De Sousa, 2010:9).

Because of pressure from the international community (including that from multilateral agencies and donor countries), governments have adopted anti-corruption packages that usually include two types of responses (new legislation and criminal law reforms; and the establishment of specialized anti-corruption agencies). According to De Sousa (2010:10), these responses attracted policymakers because they attended the request for anti-corruption measures "without necessarily having a real impact on the opportunities for corruption" (De Sousa, 2010:10).

The interplay of these multiple international actors then encroached with the strategies, visions, and interests of local players, thus reinforcing the idea of anti-corruption agencies as central pieces to national integrity systems. [...] ACAS were expected to combat corruption in an independent, knowledge-based manner by developing a specialized repressive, preventive and educational/research capacity (De Sousa, 2010:11).

The enactment of anti-corruption legislation does not necessarily result in the creation of institutions to enforce the law. Recently, countries have passed laws concerning money laundering in response to recommendations of multilateral institutions such as the Financial Action Task Force (FATF), the IMF, and the World Bank (Mugarura, 2011). In addition to institutions related to the OECD, the Council of Europe, and the UN, many regional organizations have made significant contributions to implementing such legislation. Among these organizations, the Commonwealth and Transparency International stand out (Rider 2007:6).

The relationship between legislative changes and institutional structures to implement and reinforce laws has a variety of forms in different countries. In Japan, there are anti-corruption laws that do not count on a specific agency for enforcement. In India, the Philippines, and Taiwan, for instance, multiple agencies work to enforce anti-corruption laws, while in Hong Kong, Singapore, Thailand, South Korea, and Mongolia such laws are enforced by a single entity (Quah, 2010). 


\section{SPECIALIZED COURTS: DEALING WITH CORRUPTION THROUGH PROBLEM-SOLVING COURTS}

Another institutional anti-corruption model involves specialized courts that have emerged in several countries, often because of international recommendations and pressure for legal reforms.

The literature describes specialized courts as a concentration of judges focused on a limited variety of cases; or when cases in a specific field are concentrated among a limited number of judges. Therefore, the concept may indicate a concentration of cases, or a concentration of judges (Baum, 2011:7).

Unlike in other government branches where specialization is a standard feature, in the judiciary, it has always been considered an exception because of the predominance of the understanding that judges must be generalists. However, the understanding that specialized courts promote greater efficiency and standardization gradually attracted attention from interest groups and members of the judiciary.

Baum (2011) pointed out the virtue of expertise as one of the primary justifications for specialization, and this approach has a direct impact on the recruitment of the judges responsible for each area:

If judges seek to interpret the law well, expertise helps them choose the best interpretation. If they seek to make good policy, they help them identify the case outcomes and legal doctrines that constitute good policy as they define it. High judge concentration is widely assumed to produce greater expertise and thus higher-quality policy outputs in the same way as in other organizations (Currie and Goodman, 1975, 67-68; Dreyfuss 1990, 380; Bruff 1991, 330). Further, specialization can lead to the selection of judges who are already expert in a court's field, through both self-selection and the use of expertise as a criterion for choosing judges (Dreyfuss 1990, 378). (Baum, 2011:33).

Specialization may have implications at the macro and micro levels. At the macro-level, it implies changes in legislation and the general structure of courts. In contrast, at the micro-level, it implies the selection criteria applied to cases and the recruitment of judges to work on them. 
Although the literature usually has a positive understanding of specialized courts, it also mentions some adverse effects resulting from the standardization and concentration of cases in a few courts or judges. For example, the lack of different decisions and insularity may affect policies, hinder compliance with higher court decisions, and result in bias (Baum, 2011:36). Specialization may change the ideological content of policies, influence the substance of judicial policy, and affect public policies in a specific field. In addition, specialized courts may be subject to unknown long-term effects, such as changes from their initial mission over time.

The risks associated with the judges selected - who are in the field because of their expertise, insularity, and authority (and may be less subject to review by higher courts) - are highlighted by the fact that they may tend to develop a stereotyped view of cases and may be subject to certain groups of judges, interest groups, and political interests (pro or anti-government, for example). Judges usually support the use of specialized courts often because of a perception of a potential for institutional gains (such as budget savings) and career satisfaction (recognition) as well as benefits related to self-interest and self-image. In addition, members of the judiciary may participate in other government branches, such as legislative committees.

Policymakers who make choices about judicial specialization can be influenced by a variety of interested groups. Groups that have a direct stake in cases are the most obvious seekers of influence. People with broader interests in the functioning of the courts also may participate in decisions. [...] And when legislators make choices about specialization, judges might play a significant role in shaping those decisions. (Baum, 2011:42).

Specialization in criminal justice is a model disseminated because it is understood to offer a solution to several problems. Society is usually highly supportive of specialization in criminal justice to fight crimes, particularly the elites. Criminal court judges are also supportive of specialized courts, based on the belief of their work as a mission.

Specialization in criminal justice takes place in waves, with two different types of courts. The first is a "socialization court", characteristic of progressive eras, represented by courts specialized in domestic violence, childhood and adolescence, and indigenous peoples. The second type is problem-solving courts, which tend to adopt a severe 
and punitive approach, with strong cooperation among participants, without clear limits between the performance of prosecutors, judges, and defenders. Specialized courts that address drugs, weapons, organized crime, and corruption are problem-solving courts.

Specialized courts are generally created by the endogenous action of the judiciary, promoted by judicial autonomy and facilitated by a decentralized structure that allows implementation, growth of demands for specialization from judges an entrepreneurial attitude, ensuring the necessary legislative approval. As in other courts, criminal specialization is often extremely attractive to judges, who understand that it can generate satisfaction, prestige, and power, breaking with the figure of a neutral referee to become the central element of a team.

In the case of corruption, specialized courts are created for the same reasons as anti-corruption agencies: to identify cases of corruption in existing corrupt systems and build expertise to deal with complex cases:

Frustration with the capacity of the ordinary machinery of justice to deal adequately with corruption has prompted many countries to develop specialised anti-corruption institutions. [...] In some countries, concerns about the ability of the ordinary courts to handle corruption cases impartially, and without being corrupted themselves, have also played an important role in the decision to create special anti-corruption courts (Stephenson and Schütte, 2016:4)

Although anti-corruption agencies are well known in the literature, the creation of specialized anti-corruption courts is poorly researched. There is little literature on why they are created and how they act in tandem with regular or generalist courts (Butt and Schütte, 2014:603604), and few studies offer "systematic, comparative analysis focused specifically on specialised anti-corruption courts" (Stephenson and Schütte, 2016:5).

The first examples of the creation of specialized courts in the literature include countries such as Senegal (1981), the Philippines (1984), Pakistan (1999), Uganda, India and Malaysia, and the most well-known case in Asia, Indonesia (Butt 2009a, 2009b, 2012; Butt and Schütte, 2014). Later, Stephenson and Schütte carried out a study to fill this gap, focusing on the existence of specialized anti-corruption courts, 
with attention "to the rationale for their creation and to basic design choices." The authors focused on Indonesia, Kenya, the Philippines, Slovakia, and Uganda to "provide a preliminary mapping of different types of specialised anti-corruption courts and to highlight some of the key challenges and trade-offs that must be considered when designing such institutions" (Stephenson and Schütte, 2016:5). The study found specialized anti-corruption courts in the following countries: Afghanistan, Bangladesh, Botswana, Bulgaria, Burundi, Cameroon, Croatia, Indonesia, Kenya, Malaysia, Nepal, Pakistan, Palestine, the Philippines, Senegal, Slovakia, and Uganda, in addition to Mexico, Tanzania, and Thailand, which created their courts after 2016.

Stephenson and Schütte (2016) considered Brazil and Papua New Guinea as two borderline cases. For them:

Brazil has created a set of federal-level special courts to deal with cases involving money laundering and related financial crimes. While money laundering is obviously closely intertwined with corruption, in the end we did not include the Brazilian special courts in our survey, in part because "core" corruption offenses, such as bribery and embezzlement, are not adjudicated in these courts (Stephenson and Schütte, 2016:7).

However, an analysis of the performance of specialized courts in fighting corruption in Brazil offers another perspective. Adopting the very same concept developed by Stephenson and Schütte (2016) - an anti-corruption court is "a judge, court, division of a court, or tribunal that specializes substantially (though not necessarily exclusively) in corruption cases" - this study affirms that Brazil is not a "borderline case'"', but a legitimate example of a country with specialized anti-corruption courts.

Some characteristics and principles are common to all types of institutions. Among them are: (a) independence, understood as the capacity to act without political interference, counting on operational autonomy (in terms of budget and recruitment, for instance); (b) inter-institutional and international cooperation and networks (Power and Taylor, 2011b); (c) recruitment and specialization, requiring an integrated, multidisciplinary and informed strategy; (d) a research role; (e) durability, although the establishment of an agency is a relatively easy institutional process, it is difficult to ensure its effectiveness and durability over time due to the struggle to guarantee financial and political support (De Sousa, 2010). 
The literature identifies reasons for the creation of these courts, such as efficiency, integrity, and expertise. Regarding efficiency, "a specialised court, which handles only corruption cases or similar offences, will have a more favourable ratio of judges to cases and will therefore be able to process cases more quickly" (Stephenson and Schütte, 2016:10).

As for integrity, courts are created to ensure "that corruption cases are heard by an impartial and independent tribunal, free of both corruption and undue influence by politicians or other powerful actors" (Stephenson and Schütte, 2016:12). Finally, the need for expertise is considered a reason for creating courts specialized in several issues, but it is not usually emphasized in the public discourse justifying the creation of specialized courts to fight corruption: "in most countries specialised expertise has been less prominent as a rationale for anti-corruption courts than for other sorts of specialised courts" (Stephenson and Schütte, 2016:14).

The authors add that,

[...] the degree to which specialised anti-corruption courts are actually more willing and able than regular courts to convict high-level or well-connected defendants, however, appears uneven. Some courts have been praised for their independence. [...] In many other countries, however, the anti-corruption courts have been criticised for having done too little to eliminate the culture of impunity [...]. Of course, the creation of specialised anti-corruption court is no guarantee that these courts will not themselves be corrupted (Stephenson and Schütte, 2016:13).

The next sections describe the experiences of Indonesia and Brazil to explore the convergences and divergences between the two cases and support the proposal of an analytical model for the institutional design of specialized anti-corruption courts.

\section{THE INDONESIAN ANTI-CORRUPTION EXPERIENCE THROUGH A SPECIALIZED COURT}

In Indonesia, the KPK Act of 2002 established a commission known as the KPK, [Corruption Eradication Commission] and a specialized court (Tipikor Court), with jurisdiction to investigate and decide cases prosecuted by the KPK ${ }^{2}$. The commission's main roles were to coordi- 
nate and monitor government agencies and institutions, investigate and establish procedures to address corruption cases, prevent corruption, and monitor the state's governance. As for the Tipikor Court, its purpose was "to circumvent entirely a judicial system known to be complicit in protecting corruptors, and - at the very least - capable of being unresponsive or incompetent in the administration of justice" (Fenwick apud Butt and Schütte, 2014:605).

The court was established in 2004 in Jakarta, with jurisdiction over the national territory and extending to Indonesian citizens outside the country. Among the innovations in this court is the fact that it has ad hoc judges (three ad hoc judges for each two career judges at the three levels: first instance, appeal, and cassation). Ad hoc judges are selected from among legal experts (academics, professionals, retired judges) with the justification of their independence towards the existing legal apparatus. They perform their work after receiving a short deadline case appreciated (in the first instance, the case must be settled within 90 days, the appeal must be heard within 60 days in the appellate division of the specialized court system, and the Supreme Court has another 90 days to judge it (Butt, 2012:32-33).

Butt and Schütte argue that the court was established with little controversy compared to the discussions around the establishment of the KPK. Multilateral agencies and civil society organizations advocated for completely autonomous courts in all provinces. However, only one central court was established, revealing the government's denial of institutional and budgetary support for the policy in the early years (Butt and Schütte, 2014:605-607).

In terms of performance, the Indonesian specialized court maintained a $100 \%$ conviction rate in the first six years, imposing average prison sentences of 4.81 years). In comparison, at the generalist courts, the conviction rate was $51 \%$, and the average imprisonment was about six months (Butt and Schütte, 2014:607).

The anti-corruption agency is also responsible for gathering evidence and the cooperation among its prosecutors and investigators has resulted in the specialized court's high rate of conviction and punishment. According to Butt and Schütte (2014:608), "the KPK invested heavily in its investigators and prosecutors, encouraged cooperation between investigators and prosecutors of different professional back- 
grounds and allocated more resources to case-management than the Attorney General's Office" (Butt and Schütte, 2014:608). In addition, the fact that an investigation cannot be suspended once it is started has led to better case selection criteria, prioritizing those with more substantial evidence (Butt and Schütte, 2014:608).

The capacity of the specialized courts to investigate, prosecute, and convict, raised criticism regarding the rights of defendants. The connection between judges and prosecution formed what could be understood as a "dual" or parallel system that led those selected by the specialized court to conviction. In contrast, those selected by the generalist courts had a higher chance of acquittal or receiving more lenient sentences.

These criticisms led the constitutional court of the country to rule that the existence of a dual prosecution system was unconstitutional, for violating the principle of equality before the law. The constitutional court, however, granted the policymakers three years to provide new legislation to eradicate the dual system (Butt and Schütte, 2014:609).

The solution offered by the new law was to remove jurisdiction over corruption from the generalist courts, providing that all corruption cases were dealt with exclusively by specialized courts. Specialized courts were then expanded to all of Indonesia's 34 provinces.

Other institutional change occurred, such as the removal of the requirement to recruit ad hoc judges, given the difficulty of recruiting in the provinces. This change made the decentralized specialized courts much less susceptible to central control. Also, the KPK lost its exclusivity over prosecution, allowing prosecutors (whose reputation and integrity are not considered high) to take their cases to specialized courts (Butt and Schütte, 2014:609).

As for the Constitutional Court's decision to request changes to the anti-corruption institutions based on the understanding that the specialized court constituted a parallel system, it is worth mentioning that this was not the first time the Constitutional Court opposed institutions fighting corruption. In other moments, the court had prohibited KPK from investigating and prosecuting cases that occurred before the commission was established. 
Butt (2009b) identifies an apparent dispute between the Constitutional Court and the Supreme Court, which is the highest appellate court, over the definition of "unlawfulness", which affects anti-corruption activities. The Constitutional Court considered the definition of corruption as "an act that breaks the law" as too broad and contrary to the proper execution of the legal process.

However, the literature points out that part of the criticism is due to the court's performance:

2008 marked a new era of brazenness on the part of the KPK, which, with its growing experience and capacity, was exponentially improved in professionalism and competence. After securing over 100 convictions, an emboldened KPK began targeting "big fish" corruptors, including former and serving parliamentarians and ministers, and even family members of the Indonesian president, Susilo Bambang Yudhoyono (SBY), re-elected in 2009 on an anti-corruption platform. [...] Targeting figures with more powerful political connections has drawn more intense retribution against the KPK (Butt, 2009a:303-304).

The changes have weakened the court's capacity and, according to Butt (2009a:306), "the KPK is becoming a victim of its own success."

The authors understand institutional changes and their consequences in two ways: on the one hand, changes were inevitable due to the Constitutional Court's consideration regarding the fairness of the system. On the other, it is possible to say that parliamentarians and political parties have gained much from the weakening of the anti-corruption infrastructure (Butt and Schütte, 2014:610-611).

In terms of performance, while some believe that high conviction rates may indicate good performance of the courts and, therefore, low conviction rates would show that the initiative is less successful, there is a broad debate about rights in this relationship that must be considered.

The authors conclude that:

The Indonesian case demonstrates that extreme specialization - that is, insulating the Tipikor Court from the existing system by limiting its jurisdiction and introducing special legal procedures - can undermine 
equality and fairness, if other corruption cases continue to be heard by non-specialized courts. However, attempts to mitigate these concerns by extending the Court's jurisdiction to all corruption cases and delegating its functions to provincial courts appear to lead us back to "square one". This is because it brings back into play ordinary law enforcement institutions, along with their capacity and integrity challenges. Using ad hoc judges in corruption courts in Indonesia's regions is problematic in itself. [...] More broadly, the Indonesian experience suggests that while specialized corruption courts, established to circumvent ordinary courts, might meet some initial success, they are unlikely to be an effective long-term remedy for broader systemic dysfunction amongst law enforcement agencies. This suggests that while specialized courts might provide an effective stop-gap measure, they are no substitute for broader reform of the judicial system. (Butt and Schütte, 2014:617).

The next section contextualizes the theme of fighting corruption in Brazil. It presents the current political processes in the country, introducing convergences and divergences between the process of creation and implementation of specialized anti-corruption justice in Brazil and the Indonesian experience.

\section{THE BRAZILIAN EXPERIENCE OF COMBATING CORRUPTION: THE CASE OF THE JUSTICE SYSTEM}

The specialized literature has contributed to exploring the fight against corruption in Brazil. It is possible to observe a group of studies that conceptualize (Rose-Ackerman and Palifka, 2016) and establish typologies (Karklins, 2002) for corruption, investigating origins and causes. In Brazil, corruption is related mainly to political grammars and the relationship between elite groups and the state characterized as: patrimonialism (Faoro, 2012), personalism (De Holanda, 2006), and grammars of cronyism, corporatism, and bureaucratic insulation (Nunes, 2010); as well as institutional causes (Power and Taylor, 2011b).

Another group of studies was interested in understanding the costs (Filgueiras, 2008), especially those related to imbrications between corruption and democracy (Avritzer and Filgueiras, 2011a; O'Donnell, 1998).

Finally, a third group tries to understand the variety of forms of control: administrative-bureaucratic; judicial; and the concept of Web accountability institutions (Praça and Taylor, 2014; Power and Taylor, 2011b; 
Arantes et al., 2010) to point out the creation of important institutions (federal prosecutors, Federal Police, federal judiciary). The forms of control introduced since the Federal Constitution of 1988 have undergone institutional changes, usually incremental (Aranha and Filgueiras, 2016), from an endogenous motivation of institutional affirmation, changing the design of institutions and increasing their autonomy and independence (Arantes et al., 2010; Arantes, 2015).

Over the last two decades, amid a growing number of studies that relate law and politics in Brazil, the issue of combating corruption has become a central theme in the research agenda, not only because of academic curiosity but also because of the reality in the country, which has demanded attention from the academy.

Brazilian history is marked by cycles of authoritarianism and periods of democratization. Recent Brazilian political history was marked by the most extended democratic period, after more than 20 years of military dictatorship (between 1964 and 1985). The promulgation of the 1988 Federal Constitution guaranteed rights and citizenship, and inaugurated and gave support to a new society with severe social problems, periods of crisis, and economic growth. Society could not always guarantee development, but has guaranteed free elections, respecting Dahl's concept of polyarchy (1971).

During more than 20 years of democracy, one of the significant characteristics of the state was institutional development, with the formation of a professional bureaucracy, recruited by public selection processes, and an increasing demand for more schooling.

The judiciary took advantage of this period. After the dictatorship, the judiciary had very low prestige, as a consequence of the lack of independence and considerable connivance with the military regime and its wrongdoings. The constitutionalization of rights, however, left the judiciary and other institutions of the justice system among the most important and prestigious guarantors of the nascent social status.

As a result of reforms promoted by international agencies (which initially followed the World Bank's Washington Consensus) the judiciary expanded its structure to help establish a promising capitalist system in the country. The judiciary ensured its independence and autonomy 
with an increased budget and bureaucracy and led the strengthening of other institutions in the period, such as the Public Prosecution Service (Ministério Público), Public Defenders Office (Defensoria Pública), and other institutions such as the Federal Police (Polícia Federal), which has undergone similar efforts to attain greater institutional and career development.

The recent history of the Brazilian judiciary shows the emergence of a branch that at first was not very active. In a second moment, the judiciary was still not able to appropriately respond to legal demands. Finally, in the current phase, the Brazilian judiciary is completely involved in politics and public policy. Of course, the performance of this decentralized government branch cannot be generalized. An analysis of the operation of the system shows that there is not always respect for Supreme Court positions. It is noteworthy that the degree of judicial activism and the number of judges who focus on their career development have increased over the last decades.

Another important feature related to fighting corruption in Brazil is the wide creation of specialized criminal law, which increases the criminalization of conduct and prison sentences. This approach has been used regardless of the ideological profile of the government (in the recent democratic period Brazil first had center-right governments, which were followed by center-left governments, and then the current right-wing government).

\section{SPECIALIZED CORRUPTION COURTS IN BRAZIL}

The history of implementing judicial specialization to address the issue of corruption in Brazil is little known, despite the importance of this effort. According to Butt and Schütte (2014) and Stephenson and Schütte (2016), fighting corruption has been relatively well studied in areas such as law, political science, and public policy - primarily through works describing and analyzing the process of creation and dissemination of independent anti-corruption agencies in developing countries. However, specialized anti-corruption courts have not received much attention. Knowledge of these courts is limited to information from media publications and interviews, with little academic analysis beyond reflections by practitioners. 
Different from what has been found in other countries, in Brazil, the inspiration for the creation of an anti-corruption policy did not come from civil society or the executive. The leading player was the federal judiciary, and this phenomenon deserves a closer look.

Anti-corruption campaigns in Brazil pushed the government to modernize the federal police (Arantes, 2011a, 2011b; Fagundes and Madeira, 2020) and emphasized the public prosecutors' role as a body that monitors law enforcement. After a history of institutional gains resulting from the Federal Constitution of 1988 (Arantes, 2015; Kerche and Marona, 2018), the Public Prosecutors Office took a strong position in the fight against corruption. It left behind its role as an institution that guarantees rights (a role that was partly assumed by public defenders, acting independently and with autonomy) (Madeira, 2014).

\section{THE STORY TOLD BY JUDICIAL ACTORS}

The formation of specialized courts in the Brazilian federal judiciary is an essential part of the history of justice in the country (Mathias, 2009). Before 2004, when the National Council of Justice was created as part of a reform of the judiciary implemented by Constitutional Amendment 45/2004 (Brasil, 2004), the Conselho da Justiça Federal (CJF) (Federal Justice Council) was the highest body administering and monitoring the Brazilian federal justice. It was within the scope of the CJF that the institutional structure of the specialized courts was established.

The Centro de Estudos Judiciários (CEJ/CJF) (Center for Judicial Studies) also had an important role in this process. Its creation inaugurated empirical research on the federal judicial system, marked by the first publication "A Critical Analysis of the Law on Money Laundering Crimes" in 2001 (CJF, 2002).

The research was conducted to study the context of Law 9613/1998 (Brasil, 1998) that introduced the crimes of money laundering in the Brazilian legal system and also led to policies to prevent the use of the Financial System for illegal practices (Brasil, 1998) ${ }^{3}$. The research identified that before the legislation, even though there were inquires 
related to the issue, crimes of money laundering and concealment of property were not subject to criminal sentences and convictions in the federal justice system.

The CEJ/CJF's publication led to the establishment of a commission within the CJF, formed by an interdisciplinary team, to address the legal context around these crimes (De Sordi, 2016:52). The commission included federal judges, federal prosecutors, federal tax auditors, agents from the Conselho de Controle de Atividades Financeiras (COAF) (Council of Financial Activities Control), and federal police officers.

The work of the commission pointed out that the major difficulty in applying Law 9613/1998 to money laundering was in linking it to a previous crime. Another challenge identified was the need for cooperation between the criminal prosecution bodies (Dipp, 2016:25), such as the Federal Public Prosecutorial Service (Ministério Público Federal), Federal Justice (Justiça Federal), and Federal Police.

The idea of specialization came from this commission, which issued Resolution 314/2003 (CJF 2003) to guide the implementation of courts specialized in money laundering. The next instruction on this matter was Resolution 517/2006 (CJF 2006), which implemented specialize courts to hear cases involving the crimes against the financial system (Dipp, 2016). The institutional changes occurred internally and the model of specialization was established, replicated, and disseminated throughout the country, including in many state judiciary branches (Madeira et al., 2019). The development of specialized courts has allowed the judicial system to respond faster to financial crimes and corruption.

The federal justice system is divided into five regions, each of which has its own appellate division. Currently the jurisdiction of the The Federal Appeals Court for the First Region (TRF1) has eight first instance chambers: one (1) in the state of Bahia; two (2) in the Federal District; one (1) in Goiás; one (1) in Maranhão; two (2) in Minas Gerais; and one (1) in Pará. The TRF2 has four federal chambers. TRF3 has six (6) in São Paulo. TRF4 has seven chambers: four (4) in Paraná; two (2) in Santa Catarina; and one (1) in Rio Grande do Sul. Finally, the TRF5 has four chambers: one (1) in Ceará; two (2) in Pernambuco; and one (1) in Rio Grande do Norte. 
These institutional changes, however, went beyond the judiciary and had repercussions in the executive and legislative branches.

First, the creation of the interdisciplinary commission within the Federal Justice Council (CJF) became the core of a national anti-corruption policy issued by the Ministry of Justice of President Lula da Silva's government in 2003. The policy, called the National Strategy for Combating Corruption and Money Laundering (ENCCLA), integrated all web of accountability institutions (Power and Taylor, 2011b). In this case, the federal judiciary participated in agenda-setting and formulation of public policy within the scope of the federal executive branch.

Secondly, from the commission's work and ENCCLA's developments, many legislative changes took place in the field. Among them, Complementary Law 135/2010, known as the Lei da Ficha Limpa (clean records law) (Brasil, 2010), determined that persons with criminal convictions cannot run for public offices. Then, Law 12683/2013 (Brasil, 2013a) excluded the list of specific preceding associated crimes that characterize money laundering. Therefore, since its enactment, any crimes or misdemeanors may be considered to characterize this wrongdoing, which facilitated identifying the offenders and their illegal activity and building the case for their conviction. Other legislative changes included the enactment of Law 12846/2013, the anti-corruption law (Brasil, 2013b), which provides for the recovery of criminally obtained assets; Law 12850/2013 that defined criminal organizations (Brasil, 2013c); and finally Resolution 2013/00273 of the CJF (CJF, 2013), which granted competence to specialized federal courts to prosecute transnational or domestic crimes committed by criminal organizations.

The legislative changes concerning money laundering and criminal organizations were followed by the expansion of the policy to specialize federal courts. The CJF resolution allowed an increase in the number of specialized courts for hearing cases involving money laundering and crimes against the National Financing System. Thus, in the scope of first-degree justice, the resolution gave powers to the Regional Federal Appeals Courts (TRFs) to create new specialized courts (Dipp, 2016:26). In this sense, Dipp highlights two main objectives of this policy: 
[...] incorporating recent legislative changes and ratifying the mandatory specialization in these types of crimes. The resolution incorporates the new concept of criminal organization brought by Law 12850/2013 and the changes to Law 9613/1998, [and] Law 12683/2012, which eliminated the list of crimes that precede the "laundering" per se. With this change, any criminal activity can be considered as an antecedent [to the crime of money laundering]. The expectation is that the measure reveals a higher number of "money laundering" crimes. Resolution 273, therefore, should be seen in the light of strengthening the agility of these units by determining that federal, regional courts avoid the accumulation of many suits in a single specialized court. (2016:26; our translation)

The federal judiciary, therefore, had a leading role in the movements to strengthen public anti-corruption policies that began in President Lula da Silva's administration in 2003 with ENCCLA and legislative changes in the two houses of Congress. The work of federal policy-makers, especially by the regional federal appeals court TRF4, and the formation of coalitions (Sabatier, 1988) among judges, prosecutors, bureaucrats of the control bodies (such as tax auditors), federal police, legislators, and members of the executive were central to this process.

It is still unclear whether international forums inspired the idea of specialized courts adopted in Brazil, or if international donors played a role in disseminating these courts, as suggested by Stephenson and Schütte (2016). Although Brazil has participated in the main international anti-corruption forums, it has appeared in low positions in anti-corruption rankings. According to those interviewed for this study, the creation of anti-corruption institutions in the country may be why Brazil has had a role in international anti-corruption efforts.

The emergence of the model of specialized courts and their dissemination in all regional federal appeals courts (TRFs) has taken place through diffusion and policy learning, and there is currently a tendency to use the model among state judicial systems (Madeira et al., 2019).

The changes in the specific legislation undertaken after lobbying in Congress were fundamental to developing an active and rigorous performance of the specialized courts. 
From the model created, courts specialized in financial and organized crime are problem-solving courts. Judges with expertise, legitimacy, and independence from higher courts, have had institutional support to act, although they have not always respected constitutional limits and guarantees.

The literature shows that some characteristics of the specialized courts are similar to the ones described in studies on independent agencies. Examples include durability, the power to centralize information, interinstitutional coordination and cooperation, production and transfer of knowledge (De Sousa, 2010:12). However, specialized courts interpret the law differently than other types of accountability institutions. They are the final agent of anti-corruption policy implementation, evaluating and legally defining crimes in the context of criminal prosecution.

Another well-known feature of anti-corruption agency that is also found in the specialized courts is the use of the media and a break from more traditional and discrete ways of adjudicating cases.

From the results of the implementation, the specialization of federal courts in Brazil reproduced two models for prosecuting corruption that the literature attributes to specialized agencies operating in the Global South (De Sousa, 2010; Quah, 2010; Stephenson and Schütte, 2016). The first model, originally involved generalist courts, addresses with petty corruption committed by criminals of low socioeconomic status and street-level bureaucracies. The second model deals with large corruption schemes, which are judged by specialized courts, usually in the Brazilian states where this type of crime presents a higher level of sophistication (Madeira and Geliski, 2019).

As for crimes associated with corruption, a study of the federal justice system in southern Brazil (Madeira and Geliski, 2019) identified the prevalence of trials related to crimes of smuggling and misconduct in general criminal courts. The specialized courts focus on money laundering crimes, with funds resulting from preceding crimes by criminal associations and related to offenses against the national financial system, and trafficking; and afterward, crimes against public administration. 
Different from the experience of specialized agencies in other countries, the specialized courts in Brazil operate within the framework of the federal judiciary, i.e., both spheres (specialized and generalist) are submitted to the same appellate and higher courts.

The difference between the specialized and generalist courts lies in the kind of responses by intermediate and higher courts to trial court level decisions in each model, with a stronger tendency to over-rule decisions of generalist courts and to confirm decisions of specialized courts. Unlike the Constitutional Court of Indonesia, the Brazilian Federal Supreme Court (Supremo Tribunal Federal - STF) ${ }^{5}$ has not taken a critical stance towards or over-turned many of the decisions of the specialized courts.

Bottom-up specialization eventually made lower court judges experts in the field before judges of intermediate and higher courts gained experienced with these issues. This explains why the higher courts commonly affirm decisions made at the lower level.

This phenomenon is important in the comparison between the experiences in Brazil and Indonesia. In Brazil, specialized courts receive great notoriety and resources from the Brazilian federal judiciary in general, while in Indonesia these courts do not have the same treatment. The Indonesian courts are often subject to cuts in financial and human resources, and limitations in recruitment, supervision, and support, (Butt and Schütte, 2014:606). Their recommendations to the legislative branch regarding resources needed by NGOs, government, academy, and the judiciary to fight corruption are also often neglected.

In this sense, while in other countries disputes among agencies or between agencies and the criminal justice system is common, in Brazil, there has been inter-institutional cooperation and networking. 


\section{SPECIALIZED ANTI-CORRUPTION COURTS IN COMPARATIVE PERSPECTIVE: AN ANALYTICAL MODEL OF INSTITUTIONAL DESIGN}

The analytical model for the institutional design of specialized anti-corruption courts proposed in this study seeks to understand the adoption of specialized courts as public policy and contribute to the literature by allowing comparative research between courts ${ }^{6}$.

The analysis of the specialization processes as a public policy for fighting corruption requires the use of specific parameters related to policy-making. These parameters include: (1) the agenda-setting process and the motivation of different players regarding the formulated policy, including actors in the judiciary system, in the political arena, in international agencies and donors; (2) the institutional design, the autonomy of the courts in relation to the country's judicial structure and the geographical centralization or decentralization of courts; (3) the bureaucracy related to the policy at different levels, particularly regarding recruitment processes to appoint implementing actors (judges); (4) the performance of specialized courts, measured by indicators such as criminal conviction and asset recovery; (5) the level of coordination between the departments of the criminal justice system in pursuing these cases. Finally, in a model that proposes analyzing courts which have political impacts greater than those in the daily performance of the traditional criminal justice system, two other elements need to be present: (6) institutional support or opposition regarding the adoption and implementation of the public policy (this support may be offered internally within the courts, by higher courts, and by other government branches); and (7) the impact regarding the durability or dissolution of this model of anti-corruption specialized courts, in comparison to other specialized agencies in other government branches. Table1 synthesizes the comparison between Brazil and Indonesia based on the model, pointing out divergences and convergences between the two experiences. 
Table 1

Model of the institutional design of specialized anticorruption courts': Brazil and Indonesia in comparative perspective

\begin{tabular}{|c|c|c|}
\hline \multicolumn{3}{|c|}{ Divergences } \\
\hline & Indonesia & Brazil \\
\hline $\begin{array}{l}\text { Agenda setting and formula- } \\
\text { tion (motivation and actors) }\end{array}$ & $\begin{array}{l}\text { - Isolated from a corrupt } \\
\text { judiciary } \\
\text { - Explicit support from inter- } \\
\text { national organizations }\end{array}$ & $\begin{array}{l}\text { - Lack of expertise } \\
\text { - Endogenous process that was } \\
\text { acclaimed by international } \\
\text { organizations }\end{array}$ \\
\hline $\begin{array}{l}\text { Judicial design (autonomy and } \\
\text { concentration vs. decentraliza- } \\
\text { tion of specialized courts) }\end{array}$ & $\begin{array}{l}\text { Autonomous specialized } \\
\text { courts connected to the justice } \\
\text { system } \\
\text { - Concentration in the coun- } \\
\text { try's capital }\end{array}$ & $\begin{array}{l}\text { Specialized courts within the } \\
\text { court system } \\
\text {-Dissemination among regional } \\
\text { federal courts }\end{array}$ \\
\hline Bureaucracy (recruitment) & - Ad hoc judges & - Career judges \\
\hline $\begin{array}{l}\text { Opposition or support } \\
\text { (Judicial and other govern- } \\
\text { ment branches) }\end{array}$ & $\begin{array}{l}\text { - The court was established } \\
\text { without much controversy, but } \\
\text { with subsequent opposition } \\
\text { from the Supreme Court }\end{array}$ & $\begin{array}{l}\text { - The court was established } \\
\text { without much controversy, but } \\
\text { with subsequent opposition } \\
\text { in the Federal Supreme Court } \\
\text { (STF). The specialization was } \\
\text { questioned in the Supreme } \\
\text { Court, which recognized it } \\
\text { constitutionality. }\end{array}$ \\
\hline \multicolumn{3}{|c|}{ Convergences } \\
\hline & Indonesia & Brazil \\
\hline Performance & - High conviction rates & $\begin{array}{l}\text { - High conviction rates, high } \\
\text { use of plea bargaining and plea } \\
\text { agreements }\end{array}$ \\
\hline $\begin{array}{l}\text { Degree of coordination with } \\
\text { actors in the criminal justice } \\
\text { system }\end{array}$ & $\begin{array}{l}\text { - Selectivity and identification } \\
\text { of judges with the prosecution }\end{array}$ & $\begin{array}{l}\text { - Selectivity and identification } \\
\text { of judges with the prosecution }\end{array}$ \\
\hline Court durability & $\begin{array}{l}\text { - Loss of power over time, } \\
\text { with government branches } \\
\text { acting to reduce its influence, } \\
\text { including through legislative } \\
\text { changes to impede corruption }\end{array}$ & $\begin{array}{l}\text { - Loss of power over time, with } \\
\text { government branches acting to } \\
\text { reduce its influence, including } \\
\text { through legislative changes to } \\
\text { impede corruption }\end{array}$ \\
\hline
\end{tabular}

Source: Elaborated by the authors, based on the literature and data (documents, interviews, reports) from the research project Federal Justice in the formulation and implementation of a national anti-corruption policy, 
The analysis shows that the main convergences refer to how these courts act on crimes of corruption. Both have high degrees of coordination with the prosecuting agencies, selectively chose and judge the cases, and issue severe sentences. The divergences are in the differences in the actors who supported the idea in the first steps of agenda-setting and policy formulation. In Indonesia, international actors took the lead in the process of insulating the judiciary. In Brazil, judges sought support from international forums to implement specialization within the justice system. As for design and implementation, in Indonesia, autonomy and exclusive recruitment of bureaucracy are guaranteed, while in Brazil, endogenous institutional changes do not modify the rules for recruitment and selection in the specialized courts. Unlike Indonesia, in Brazil, this policy led to an expanded power of judges and the judiciary, reinforcing the struggle for autonomy and independence of these judges and courts, and expanding their participation in the political arena.

There are also differences observed in the support from the judiciary and other government branches: both Indonesia and Brazil had support for creation of the courts, but in Indonesia, the Supreme Court exercised greater control.

The next section shows that these well-recognized experiences are under attack in both countries. Nevertheless, the solutions found in each of the countries reveal the endogenous characteristics and the political grammar of each case. In Indonesia, there are attempts to make the specialized court less effective and less rigorous through decentralization and changes in recruitment. In Brazil, the establishment of a coalition among judges, prosecutors, bureaucrats of the control bodies, federal police, legislators, and members of the executive branch seems to have "solved" the problem of a court that, as will be described below, exceeded its boundaries, and must now be dissolved. However, it has fulfilled its political and particularly its electoral role. 


\section{CRITICISMS AND CONNECTIONS BETWEEN POLITICS AND JUSTICE IN THE BRAZILIAN JUDICIAL SYSTEM: WILL SPECIALIZED COURTS BE SHORT LIVED?}

Different from what was observed in Brazil, the specialized courts in other countries are usually exogenous and are established through institutions that are independent from the pre-existing criminal justice system. These courts are imposed by international agencies, and created with the support of civil society, and they aim to insulate the fight against corruption from already corrupted structures.

What happened in Brazil? The process of creation of the specialized courts was endogenous, controlled and conducted by the judiciary, without external players, with members of the judiciary lobbying other government branches. The connection between judges and international organizations was direct and contributed to the process. This connection helped the anticorruption policy agenda to reach the executive, which resulted in necessary changes in legislation.

The model seems to be the same as that used to create independent agencies, in which international recommendations, participation in forums, and the role of donors indirectly play a part. However, the Brazilian case did not present one of the main features found in other countries that established independent agencies, i.e., the fact that Brazil's specialized courts were designed to deal with and prevent the corruption of judicial system institutions.

It is interesting that, in most countries, the establishment of commissions preceded the creation of the courts. In Indonesia, courts and commissions were created simultaneously, due to mistrust in the judiciary (generalist courts). In Brazil, however, the specialized court was established without any prior commission. This model demonstrates the political role of the Brazilian judiciary regarding agenda setting and formulation of public policies. The judiciary defended the use of specialized courts because of the complexity of corruption and a lack of its understanding, not because of endemic corruption in the judicial system. 
Particularly in Brazil, but also in other international experiences, including Indonesia, the performance of the specialized courts helped them to gain support and legitimacy from part of the population, and criticism, and lack of legitimation from another.

On the one hand, in specialized court model there is a call for greater reinforcement and cooperation in investigations, and permeable frontiers among the roles played by judges, prosecutors, and investigative police. On the other hand, condemnations have been criticized for being made without robust evidence. Moreover, the specialized courts have been accused by some sectors of failing to protect constitutional rights and proper criminal proceedings.

All these elements are observed in the most famous case of the Brazilian specialized courts, Operation Car Wash. The case has been well exposed in the media, since it involved numerous politicians and business people, and recuperated large sums of financial resources. However, the operation also attracted media attention due to denunciations that it violated ethical and legal limits in the relationship between the prosecutors and the judge. The accusations raised criticisms from central actors of the legal system who had been involved in the creation of the specialized courts; it also led the operation to lose legitimacy both within the judicial system and among the population in general.

In the case of Indonesia, the specialized courts had strong opposition from the Supreme Court. In Brazil, however, it is still unclear how the highest court will approach cases where specialized courts may have trespassed the limits of fundamental values, principles of law and judicial proceedings.

It is too early to identify the consequences of all these movements. However, the federal courts clearly had a leading role in the formulation and implementation of anti-corruption policy in Brazil. This role profoundly affects the relations between justice and politics in the country. 


\section{NOTES}

1. The interviews helped to understand the development of the courts specialized in trials involving money laundering. The interviewees worked at the Federal Justice Council (CJF) and the Federal Regional Court of the 4th Region (TRF4). The interviews contributed to combine information collected from document research and the reality of the actors in the field.

2. Butt analyzes the creation and role of the KPK in various papers (Butt, 2009b; Butt and Schütte, 2014). As this article focuses on the court's role, issues regarding the commission are not addressed. Notwithstanding, it is important to mention that the commission was created just before the court as an independent institution that relies on the national budget but has a mandate to work without influence from political parties and the executive, legislative, and judiciary branches. The commission headquarters is in Jakarta, and the institution works throughout the country.

3. The same law provides for the creation of the Conselho de Controle de Atividades Financeiras (COAF) (Council of Financial Activities Control). COAF "aims to control; apply administrative penalties; and receiving, examining, and identifying occurrences of illicit activities" (Brasil, 1998, article 14).

4. The information about the specialized courts was provided by the CJF's Assessoria Técnica de Estudos e Pesquisas (ASTEP) in July 2018.

5. The Federal Supreme Court is the highest court of the Brazilian judiciary, exercising constitutional control. Brazil's Federal Supreme Court also acts as the final court of appeal for all judicial demands. These two roles are performed by two different courts in Indonesia. The Constitutional Court performs constitutional control and the Supreme Court is the final court of appeal.

6. When dealing with institutional design, Stephenson and Schütte (2016) point out five aspects to consider in specialized anti-corruption courts: the relationship of the special anti-corruption court to the regular judicial system; the size of anti-corruption courts; the procedures for appointing and removing special judges; the substantive scope of the anti-corruption court's jurisdiction; and the relationship to prosecutorial authorities. 
An Analytical Model of the Institutional Design of Specialized Anti-corruption Courts

\section{REFERENCES}

ARANHA, Ana Luiza; FILGUEIRAS, Fernando. (2016), “Instituições de accountability no Brasil: mudança institucional, incrementalismo e ecologia processual". Cadernos Enap, 44. Brasília.

ARANTES, Rogério B. et al. (2010), "Controles Democráticos sobre a administração pública no Brasil: Legislativo, tribunais de contas, Judiciário e Ministério Público". In: F. L. Abrucio; M. R. Loureiro; R. S. Pacheco (eds.), Burocracia e Política no Brasil: desafios para a ordem democrática no século XXI. Rio de Janeiro: Editora FGV, pp. 109-147.

ARANTES, Rogério B. (2011a), “Polícia Federal e construção institucional”. In: L. Avritzer; F. Filgueiras (eds.), Corrupção e sistema político no Brasil. Rio de Janeiro: Civilização Brasileira, pp. 99-132.

. (2011b), "The Federal Police and the Ministério Público". In: T. J. Power; M. M. Taylor (eds.), Corruption and Democracy in Brazil: the struggle for accountability. Notre Dame: University of Notre Dame Press, pp. 184-217.

. (2015), "Rendición de cuentas y pluralismo estatal en Brasil: Ministerio Público y Policía Federal". Desacatos, nº 49, pp. 28-47.

AVRITZER, Leonardo (ed.). (2008), Corrupção: ensaios e críticas. Belo Horizonte: Editora UFMG.

AVRITZER, Leonardo; FILGUEIRAS, Fernando. (2011a), “Corrupção e controles democráticos no Brasil". CEPAL. Available at: https:/ / repositorio.cepal.org/handle/11362/28145\#. XORr3k2ETrM.mendeley (Accessed: 21 May 2019).

. (2011b), Corrupção e sistema político no Brasil. Rio de Janeiro: Civilização Brasileira.

BAUM, Lawrence. (2011), Specializing the Courts. (Chicago Series in Law and Society), Chicago: University of Chicago Press.

BRASIL. (1998), Lei no 9.613, de 3 de março de 1998. Published in the DOU of 4.3.1998. Available at: http://www.planalto.gov.br/ccivil_03/leis/19613.htm

. (2004), Emenda Constitucional $n^{\circ} 45$, de dezembro de 2004. Published in the DOU of 3.12.2004. Available at: http:/ / www.planalto.gov.br/ccivil_03/constituicao/emendas / emc/emc45.htm

. (2010), Lei Complementar $n^{\circ} 135$, de 4 de junho de 2010. Published in the DOU of 7.6.2010. Available at: http://www.planalto.gov.br/ccivil_03/leis/lcp/lcp135.htm

. (2013a), Lei $n^{\circ} 12.683$, de 9 de julho 2013. Published in the DOU of 10.7.2012. Available at: http://www.planalto.gov.br/ccivil_03/_Ato2011-2014/2012/Lei/L12683.htm

. (2013b), Lei $n^{\circ} 12.846$, de $1^{\circ}$ de agosto de 2013. Published in the DOU of 2.8.2013. Available at: http:/ /www.planalto.gov.br/ccivil_03/_ato2011-2014/2013/lei/112846.htm

. (2013c), Lei $n^{\circ} 12.859$, de 2 de agosto de 2013. Published in the DOU of 5.8.2013 - extra edition. Available at: http: / / www.planalto.gov.br/ccivil_03/_ato2011-2014/2013/lei/ 112850.htm

BUTT, Simon. (2009a), "Asian law in translation: translator's note on the Indonesian Corruption Court Law-the unravelling of Indonesia's anti-corruption framework through Law and Legal Process". Australian Journal of Asian Law, vol. 11, n 2, pp. 302-307. 
Lígia Mori Madeira and Leonardo Geliski

. (2009b), "'Unlawfulness' and corruption under Indonesian law". Bulletin of Indonesian Economic Studies, vol. 45, n 2, pp. 179-198.

. (2012), Corruption and Law in Indonesia. New York: Routledge (Routledge contemporary Southeast Asia series).

; SCHÜTTE, Sofie Arjon. (2014), "Assessing judicial performance in Indonesia: the court for corruption crimes". Crime, Law and Social Change, vol. 62, n 5, pp. 603-619.

CJF (Conselho da Justiça Federal). (2002), Uma análise crítica da Lei dos Crimes de Lavagem de Dinheiro. Série Pesquisas do Centro de Estudos Judiciários (CEJ), 9. Brasília-DF, without pagination.

. (2003), Resolução $n^{\circ} 314$, de 12 de maio de 2003. Available at: https: / / www2.cjf.jus.br / jspui/bitstream/handle/1234/3322/RES\%20314-2003.pdf?sequence=1

. (2006), Resolução no 517, de 30 de junho de 2006. Available at: https:/ /www2.cjf.jus.br / jspui/bitstream/handle/1234/3664/RES\%20517-2006\%20rev.pdf?sequence=1

. (2013), Resolução no CJF-RES-2013/00273 de 18 de dezembro de 2013. Available at: https:/ / www2.cjf.jus.br/jspui/bitstream/handle/1234/47399/Res\%20273-2013.pdf?sequence=4

DAHL, Robert Alan. (1971), Polyarchy: participation and opposition. New Haven: Yale University Press.

DE HOLANDA, Sergio Buarque. (2006), Raízes do Brasil: edição comemorativa 70 anos. São Paulo: Companhia das Letras.

DE SORDI, Neide Alves Dias. (2016), “CEJ: produção, gestão e disseminação do conhecimento na Justiça Federal". Revista CEJ, Ano XX, nº 69, pp. 49-63.

DE SOUSA, Luís. (2010), “Anti-corruption agencies: between empowerment and irrelevance”. Crime, Law and Social Change, vol. 53, n 1, pp. 5-22.

DIPP, Gilson Langaro. (2016). “Crime organizado e a importância das varas especializadas da Justiça Federal". Revista CEJ, Ano XX, n 69, p. 24-26.

FAORO, Raymundo. (2012), Os donos do poder: formação do patronato politico brasileiro. 5th ed. São Paulo: Globo Livros.

FAGUNDES, Andrea Lucas; MADEIRA, Lígia Mori. (2020). “Desenvolvimento institucional e autonomia de investigação: o que será da PF?". Published in JOTA, on april 23, 2020. Available at: https:/ / www.jota.info/opiniao-e-analise/colunas/judiciario-e-sociedade/ desenvolvimento-institucional-e-autonomia-de-investigacao-o-que-sera-da-pf-23052020

FILGUEIRAS, Fernando. (2008), “Marcos teóricos da corrupção”. In: L. Avritzer et al. (eds.), Corrupção: ensaios e críticas. Belo Horizonte: Editora UFMG.

KARKLINS, Rasma. (2002), “Typology of post-communist corruption”. Problems of post-communism, vol. 49, n 4, 22-32.

KERCHE, Fábio; MARONA, Marjorie. (2018), “O Ministério Público na Operação Lava Jato: como eles chegaram até aqui?”. In: F. Kerche; J. Feres Júnior (eds.), Operação Lava Jato e a democracia brasileira. São Paulo: Editora Contracorrente, pp. 69-100.

MADEIRA, Lígia Mori. (2014), "Institutionalisation, reform and independence of the Public Defender's Office in Brazil". Brazilian Political Science Review, vol. 8, nº 2, pp. 48-69. 
; GELISKI, Leonardo. (2019), "The Federal Justice act in combating corruption in Southern Brazil". Revista de Administração Pública, vol. 53, nº 6, pp. 987-1010.

MADEIRA, Ligia Mori et al. (2019), "Judicial policy diffusion: a model to analyse specialised state courts fighting organized crime in Brazil". Sociologies in Dialogue, vol. 5, $\mathrm{n}^{\circ}$ 2, pp. 24-51.

MATHIAS, Carlos Fernando. (2009), Notas para uma história do judiciário no Brasil. Brasília: Fundação Alexandre de Gusmão.

MUGARURA, Norman. (2011), “The institutional framework against money laundering and its underlying predicate crimes". Journal of Financial Regulation and Compliance, vol. 19, no 2, pp. 174-194.

NUNES, Edson de Oliveira. (2010), A gramática política do Brasil: clientelismo, corporativismo e insulamento burocrático. 4th ed. Rio de Janeiro: Garamond.

O'DONNELL, Guillermo. (1998), "Horizontal accountability and new polyarchies". Working Paper \# 253, April, Kellogg Institute. Available at: https://kellogg.nd.edu/sites/default/ files/old_files/documents/253_0.pdf

POWER, Timothy J.; TAYLOR, Matthew M. (2011a), Corruption and democracy in Brazil: the struggle for accountability. Notre Dame: University of Notre Dame Press.

. (2011b), "Introduction: accountability institutions and political corruption in Brazil". In: T. J. Power; M. M. Taylor (eds.), Corruption and democracy in Brazil: the struggle for accountability. Notre Dame: University of Notre Dame Press, pp. 1-28.

PRAÇA, Sérgio; TAYLOR, Matthew M. (2014), "Inching toward accountability: the evolution of Brazil's anticorruption institutions, 1985-2010". Latin American Politics and Society, vol. 56, $\mathrm{n}^{\circ}$ 2, pp. 27-48.

QUAH, Jon ST. (2010), "Defying institutional failure: learning from the experiences of anti-corruption agencies in four Asian countries". Crime, Law and Social Change, vol. 53, $\mathrm{n}^{\circ} 1$, pp. 23-54.

RIDER, Barry AK. (2007), “Recovering the proceeds of corruption". Journal of Money Laundering Control, vol. 10, $\mathrm{n}^{\circ} 1$, pp. 5-32.

ROSE-ACKERMAN, Susan; PALIFKA, Bonnie J. (2016), Corruption and government: causes, consequences, and reform. New York: Cambridge University Press.

SABATIER, Paul A. (1988), "An advocacy coalition framework of policy change and the role of policy-oriented learning therein". Policy Science, vol. 21, n 2-3, pp. 129-168.

STEPHENSON, Matthew C.; SCHÜTTE, Sofie A. (2016), “Specialised anti-corruption courts: a comparative mapping". Report published in U4 Issue, December, $\mathrm{n}^{\circ}$ 7. Available at: https://www.u4.no/publications/specialised-anti-corruption-courts-a-comparative-mapping. 


\section{RESUMO}

Um Modelo Analítico do Desenho Institucional das Cortes Especializadas Anti-Corrupção no Sul Global: Brasil e Indonésia em Perspectiva Comparativa

Este artigo descreve a experiência brasileira de combate à corrupção através de varas criminais especializadas, apresentando a criação, principais características e pontos de contato e divergência em comparação com o caso bem conhecido do tribunal especializado da Indonésia, de modo a propor um modelo de análise de desenho institucional de cortes especializadas anticorrupção. A pesquisa adota uma abordagem qualitativa utilizando análise de conteúdo, baseada em relatórios emitidos por órgãos multilaterais, documentos legislativos e judiciais e entrevistas. Enquanto no Brasil as varas especializadas recebem grande notoriedade e recursos, na Indonésia, os tribunais são negligenciados em termos de recursos financeiros e humanos, recrutamento, supervisão e apoio. Diferente da Indonésia, o processo de criação de varas especializadas foi endógeno no Brasil, controlado e conduzido por membros do judiciário com participação nos demais poderes. O movimento interno em torno das políticas para combater a corrupção e a conexão direta entre juízes e organizações internacionais levou ao apoio do Executivo e a mudanças na legislação no Congresso.

Palavras-chave: varas e cortes especializadas; combate à corrupção; política judicial

\section{ABSTRACT \\ An Analytical Model of the Specialized Anti-corruption Courts' Institutional Design in the Global South: Brazil and Indonesia in Comparative Perspective}

This article introduces the Brazilian experience of fighting corruption through specialized courts, presenting their creation, main characteristics, and convergences and divergences in comparison with the well-known case of the specialized court of Indonesia. The study proposes an analytical model of the specialized anti-corruption courts' institutional design. It adopts a qualitative approach using content analysis based on reports issued by multilateral agencies, legislative and judicial documents, and interviews. While in Brazil, specialized courts receive great notoriety and resources, in Indonesia, courts are neglected in terms of financial and human resources, recruitment, supervision, and support. Different from Indonesia, the process of creating specialized courts was endogenous in Brazil, controlled and conducted by members of the judiciary in courts and lobbying other government branches. The internal movement around the policies to address corruption and the direct connection between judges and international organizations led to the executive's support and legislation change in Congress.

Keywords: specialized courts; anti-corruption; judicial policy 


\section{RÉSUMÉ}

Un Modèle Analytique de la Conception Institutionnelle des Tribunaux Anticorruption Spécialisés dans le Sud: Le Brésil et l'Indonésie dans une Perspective Comparative

Cet article décrit l'expérience brésilienne de lutte contre la corruption à travers les tribunaux pénaux spécialisés, présentant la création, les principales caractéristiques et points de contact et divergences par rapport au cas bien connu du tribunal spécialisé d'Indonésie, afin de proposer un modèle d'analyse institutionnelle de la conception des tribunaux spécialisés dans la lutte contre la corruption. La recherche adopte une approche qualitative utilisant l'analyse de contenu, basée sur des rapports publiés par des organes multilatéraux, des documents législatifs et judiciaires et des entretiens. Alors qu'au Brésil, les tribunaux spécialisés bénéficient d'une grande notoriété et de ressources, en Indonésie, les tribunaux sont négligés en termes de ressources financières et humaines, de recrutement, de supervision et de soutien. Contrairement à l'Indonésie, le processus de création de tribunaux spécialisés était endogène au Brésil, contrôlé et dirigé par des membres du Pouvoir Judiciaire avec la participation des autres branches du gouvernement. Le mouvement interne autour des politiques de lutte contre la corruption et le lien direct entre les juges et les organisations internationales ont conduit au soutien de l'Exécutif et à des changements de législation au Congrès.

Mots-clés: tribunaux spécialisés; lutte contre la corruption; politique judiciaire

\section{RESUMEN}

Un Modelo Analítico del Proyecto Institucional de los Tribunales Especializados Anticorrupción en el Sur Global: Brasil e Indonesia en Perspectiva Comparada

Este artículo describe la experiencia brasilera de combate a la corrupción a través de salas penales especializadas, presentando la creación, principales características y puntos en común y de divergencia, en comparación con el caso bien conocido del tribunal especializado de Indonesia, a fin de proponer un modelo de análisis de diseño institucional de cortes especializadas anticorrupción. La investigación adopta un abordaje cualitativo utilizando análisis de contenido, basado en informes emitidos por órganos multilaterales, documentos legislativos y judiciales y entrevistas. Mientras que en Brasil las salas especializadas reciben una gran notoriedad y recursos, en Indonesia, los tribunales son desatendidos en términos de recursos financieros y humanos, reclutamiento, supervisión y apoyo. A diferencia de Indonesia, el proceso de creación de salas especializadas fue endógeno en Brasil, controlado y conducido por miembros del poder judicial con participación 
en los demás poderes. El movimiento interno en torno a las políticas para combatir la corrupción y la conexión directa entre jueces y organizaciones internacionales significó el apoyo del Ejecutivo y cambios en la legislación en el Congreso.

Palabras clave: salas especializadas; combate a la corrupción; política judicial 